\title{
The Social Potential Of the Polish Art in the Transformation Period
}

\author{
Artur Pstuszek \\ Doctor of Philosophical Sciences, Department Of Multimedia Institute Of Visual Arts \\ Faculty Of Arts University Of Zielona Góra \\ (Zielona Góra, Poland) \\ E-mail: a.pastuszek@wa.uz.zgora.pl \\ ORCID: 0000-0002-8966-7711
}

The transformation of the political system, which took place in Poland at the turn of the 1980s and 1990s, was accompanied with profound changes not only in economic and political rules, but also in social life.

The author assumes that the transformational potential of the artistic practice - in particular that of the Polish socially engaged art of the time, i.e. artists of the critical art movement - could be used to profile social and economic changes, especially in light of the fact that art provided a reflection of the then dominating feeling of atomisation of the political space.

The present analysis refers to a specific parallel between the mechanisms of power and artistic strategies. What is also emphasised is the political power assumed by artistic practices - manipulative skills, operational efficiency and techniques used by artists to influence the audience.

The question is why the transformational potential of the Polish art has not been fully exploited in the last decades.

Keywords: transformation, imaginary, critical art, socially engaged art, reconfiguration.

Received March 1, 2018; accepted March 21, 2018

Future Human Image, Volume 9, 2018:

DOI: $10.29202 /$ fhi $/ 9 / 8$

\section{Introduction}

At the turn of the 1980s and 1990s, Poland underwent a transformation of the political system, which aimed towards establishing new economic rules enabling the transition to a system based on the principles of free market, creation of civil society and democratisation. However, irrespective of the attempts to analyse and evaluate this process together with the then political context and social consequences, the common impression of the transformation is often reduced to "getting rid of the dysfunctional communist system (sometimes called socialism) and

(C) Pstuszek, Artur, 2018 
normalisation - in other words introducing a set of natural and universally beneficial market solutions typical of a capitalist system" [Sowa, 2016: 5]. Regrettably, our historical knowledge on these processes, even though they do not belong to a distant past, is still a conglomerate of popular notions surrounded by nothing more than assumptions and interpretations of facts. As Jan Sowa suggests, referring to observations made by a French historian Daniel Beauvois, who has studied the winding paths of the Polish history, Polish historical discourse avoids an adequate explanation of both the prerequisites for transformation and its effects, oscillating between the real and the imagined. In his works, Daniel Beauvois deconstructs Polish historical myths from the perspective of an external, critical observer, discussing topics that had not been addressed before, such as violence and cruelty of the Polish farm and feudal service, the illusoriness of the national solidarity myth, the illusion of tolerance and coexistence of different cultures and denominations within the borders of the Polish-Lithuanian Commonwealth and the reality of the Polish colonialism in the past. Consequently, there emerges an imaginary, which comprises not only ideas and theoretically-framed historical reconstructions of events, but also imagined dimensions - individually profiled practices of daily life, images, legends, myths, and superstitions. Building such illusionary historical context does not only have a consolidating and persuasive function but might also be an answer to the social need for myths observed by Mircea Eliade or the deficit of magical thinking ascertained by Giorgio Agamben.

\section{I}

This should not be surprising as politics and history are closely related, and the politicisation of history, like all manipulations related to the collective memory, has been evident in the states once dominated by totalitarian regimes. This stems from the fact that history was an extremely effective tool of ideological expansion. Generated visions of history served to build collective imaginaries, instruments to consolidate and create the core of national identity. In consequence, distribution of specific content increased the effectiveness of controlling the dynamics of collective memory and disciplining social groups.

Perhaps this lack of consistency in regulating collective memory resources - caused above all by letting the Catholic Church participate in the process - together with unsuccessful fight against the opposition resulted in a gradual separation of two mutually exclusive visions of history: its official and contested versions, built on controversies and alternative interpretations that disallow any assimilation. Following Michel Foucault, it can also be assumed that the classic historical discourse (Roman-type history), which legitimises the power, is usually accompanied with an unmasking discourse, the counterhistory (contre-histoire), which is critical towards the power and exposes secrets that the regime deliberately conceals in the shadows of oblivion [Foucault, 1998]. The history of sovereign power, a narration which attempts to recreate "the great uninterrupted jurisprudence of power", would thus be constantly confronted with the history of servitude and exile, a story whose aim is to "decipher secrets" and "demystify the power". [Foucault, 1998: 83]. Although both would be cognitively efficient, it is the counterhistory that would have a revolutionary potential by unmasking internal conflicts and antagonisms concealed by those in power.

Therefore, when the time of transformation weakened the dominating official discourse supported by the Polish authorities and revealed a number of manipulations and misrepresentations, the alternative version of history could triumph. This version, however, was also schematised and simplified in order to construct a new founding myth. This is why an adequate reinterpretation 
of the Polish history requires abandoning the glorification of the "golden age" and distancing oneself critically from one's own traditions and national myths, which for the time being is a task for subsequent generations of historians.

The time of transformation released a range of discourses and practices, which had been previously restrained by an ideological muzzle. However, it would be difficult to identify specific fields of art that would be strongly correlated with this period. It should be remembered that the notion of transformation involves a process, transition from one state to another, which is gradual rather than revolutionary. The same is true of transformations related to artistic projects. What became real in the field of economy and politics through the transformation of the socialist model into a social market economy had to wait for its artistic representation. This extremely interesting time of dynamic political, social and economic changes saw the emergence of the rules of the art market, which had previously existed only in a hypothetical form. Works of art were gradually included in the general circulation of goods. However, as in the case of new regulations in social life, many artistic solutions were temporary and did not receive institutional support. Moreover, one should remember that the reality that replaced the so-called real socialism did not create favourable conditions for creating an art market that would function in the same way as in the Western European states. This is why the 1990s are, above all, a time of redefining, experimenting with and modifying the Polish art.

The open and ambivalent character of this period made Jakub Banasiak describe it as nontime, a transitional moment, formless, dominated by potentiality, in which reality could take any shape: "The non-time of the nineties could be (...) described as a natural state or a kind of resetting. All these concepts designate basically one thing: a state of void which was to be filled with great narrations of the transformation period" [Banasiak, 2011].

One of such narrations was proposed by critical art. This movement in Polish socially engaged art of the 1990s was the first to react to the dilemmas and problems related to transformation, postulating a distanced, critical reflection and cultural commentary, exploration and demystification of the changing social and political reality, exposition of ambiguity and ambivalence and exposure of the disciplining strategies of the authorities. The movement was created by artists who debuted in the eighties, such as Zbigniew Libera and Grzegorz Klaman, as well as younger artists associated with Grzegorz Kowalski's atelier, who began their careers in the mid-nineties, such as Artur Żmijewski, Katarzyna Kozyra, Jacek Markiewicz and Paweł Althamer, but also Alicja Żebrowska, Dorota Nieznalska and Robert Rumas. Constructed on the basis of counterhistory discourse and exposing the shortcomings and misrepresentation of the dominating narration, the project reflected a search for a new order — the future, transformed horizon of social life. However, in the fluctuating world of deep and dynamic changes dominated by uncertainty, the lack of permanence or stability, the feeling of being lost, and the need to arrange a permanent order had to assume a different shape. This is why Polish artists resorted to techniques developed in the Western counterculture: subversion and recontextualisation (detournement), body art or even abject art.

In this way, critical art was able to weaken the myths that had been generated to validate the existing order, argue with the proposed interpretations of national history, condemn power discourses and point to social engagement methods. By acting in an unconventional and often controversial way, critical art could galvanise, stimulate reflection, arouse emotions, but also provoke indignation.

A good example of this function can be found in most works by Zbigniew Libera, a scandalising and controversial artist, who deconstructs the area of stereotypical social roles and 
canonical discourses. Among his works are the video Jak tresuje się dziewczynki / How to Train the Girls (1984), a body-building set for little boys (Body Master, 1995), an installation imitating the sign on the gate of the Auschwitz concentration camp (Christus ist mein leben, 1990), a device for penis enlargement (Universal Penis Expander, 1995), and his most recognisable work, a Lego set for building a death camp (Lego. Obóz koncentracyjny/Lego. Concentration Camp, 1996). All of these works caused many "allergic" reactions. Other artists whose works have a critical, demystifying and iconoclastic character and emancipatory power include Dorota Kozyra (for example her diploma work Piramida zwierzat/Pyramid of Animals, 1993, or the subsequent well-known Łaźnie/Bathhouses 1997 and 1999) and Artur Żmijewski (videos Oko za oko/ Eye for an Eye, 1998, KRWP, 2000, Berek/Tag, 1999, and 80064, 2002). A spectacular example of a scandal generated by the public media are actions and repercussions (social protests and institutional sanctions) against the works of Nieznalska (Pasja/Passion, 2001) and Markiewicz (Adoracja Chrystusa/Adoration of Christ, 1993).

Unfortunately, viewers at that time were unprepared for this kind of art due to lack of cultural education. In most cases the works were perceived as an incomprehensible attack on reception habits and traditional forms of art. The same is true of the so-called elites who behaved in the same way as the rest of the society. Their reaction to the manifestations of critical art was uniformly negative due to the fact that their knowledge of art was limited to the most canonical examples. Indeed, this is still characteristic of the majority of Poles. Due to lack of knowledge and little competence, contemporary art is marginalised as incomprehensible. As a result, its social role is not recognised. This fact has been confirmed by studies [Krajewski \& Szmidt, 2016: 8-12], which also demonstrate Poles' preferences: they expect art to fulfil aesthetic (source of satisfaction and positive emotions), cognitive (source of information or reflection), pragmatic (object that can be used in practice) and social functions [Krajewski \& Szmidt, 2016: 20-21].

\section{II}

Therefore, when assessing the time of transformation in terms of how important the voice of artists engaged in the process was, one could risk a claim that this period was somewhat squandered. It is true that, having critically evaluated the transformation, art was not afraid to take up the challenge of deconstructing the image of history sanctioned by social imaginaries, to contest the leading narrations of the past, to problematise the scale and to demythologise official discourses. However, these actions where never institutionally supported. What is more, the critical discourse did not generate mechanisms of self-regulation and the new reality brought not only enthusiasm, but also new problems and frustrations. At the same time, critical art turned out to be an ephemeron, whose social potential quickly expired due to its form and cultural context, which passed without continuation (its history comes to an end quite rapidly in spite of the fact that the artists originating in this movement are still active).

Nevertheless, the emblematic character of the transition years is related to critical art and even if its social capital was not effectively used, it was an exceptional time of artistic radicalism. It paved new ways in the Polish approach to thinking about art. There is also some hope in the actions and statements of the critical artist themselves, who, looking back, acknowledge this untapped potential. Artur Żmijewski, the current artistic supervisor of "Krytyka Polityczna" magazine and the curator of the 7th Berlin Biennale, to which he invited representatives of social and city movements together with political activists, says in an interview with the co-curator Joanna Warsza: "I have always been more interested in the social and political usefulness and 
effectiveness of artistic activity. I have been wondering how you can use the language of art to put people into a state of ideological tremor and to become as skilled in manipulation as politicians are" [Żmijewski, 2012]. Żmijewski is aware of the political power of art and its emancipatory potential, yet sceptical about its effectiveness. It should be remembered, however, that this period started a series of unprecedented attacks on works of art and the galleries where they were displayed, and that binary oppositions that divided the artistic community in parallel to political divisions, were also present in the field of art perception.

On 17 November 2000, the actor Daniel Olbrychski came to Zachęta National Gallery of Art in Warsaw with a film crew of the public broadcaster (TVP). The actor entered the gallery with a saber and used it to destroy part of Piotr Uklański's installation Nazis, which consisted of 164 colourful film photographs depicting attractive actors who had played the roles of German soldiers from the time of the Second World War. Later Olbrychski explained that he did it as an act of defending his own dignity and the dignity of his colleagues whom Uklański identified with the characters they played. Olbrychski was unable to understand Uklański's deceptive game of playing with popular culture clichés, but at the same time he reached for a rather spectacular tool himself — he staged a performance with the use of a prop (Kmicic's saber) and had it recorded. Due to an (unfounded) suspicion of Nazism propagation, the then Minister of Culture and Art, Kazimierz Michał Ujzadowski, decided to close the exhibition.

However, as noticed by Stach Szabłowski, this event gained a symbolic status as the first case when "an aversion to an artistic proposal left the sphere of debate and took the shape of physical violence - a radical act of iconoclasm targeted at contemporary art and its strategies" [Szabłowski, 2009]. What is more, Olbrychski removed the image of one of his film characters (Karl Kremer from Les uns et les autres by Claude Lelouch, 1981) using an artefact belonging to another character he played (Kmicic from Potop (The Deluge) by Jerzy Hoffman, 1974) in a symbolic fight against representations of new culture with an archaic weapon of the Polish nobility [Szabłowski, 2009].

Another spectacular example of a conflict which escalated around a work of art was the behaviour of a Polish MP Witold Tomczak. On 21 December 2000, the politician visited Zachęta Gallery together with his colleague from the same political club, Halina Nowina-Konopczyna. Driven by patriotic and religious motives, he felt the need to "correct" Maurizio Cattelano's sculpture La Nona Ora, which presented Pope John Paul II squashed by a meteorite, by relieving the Head of the Church of his burden. Despite security's intervention, the MP succeeded in removing the heavy object from the Pope's body — sadly, together with one of the Holy Father's lower limbs.

These events not only exemplify a situation when conservatism and ignorance are confronted with new, radical or critical artistic strategies, but also confirm the fact that authorities may intercept artistic practices - the performative power of works of art is taken over by politicians' activities and various forms of social protests. Thus, political actions (debates, manifestations, demonstrations) could be described as spectacles organised according to the rules (of art). This seems to confirm an observation that performativity and spectacularity are those aestheticising strategies that were annexed by the popular culture most efficiently.

The entire situation raises the issue of why such a complementary and relevant (functioning within the context of social dynamics) artistic project, which additionally had an enormous political potential, was unsuccessful. The observed political involvement of art calls for a detailed and adequate explanation — not only with regard to rather obvious usefulness of artistic practice and its instruments (strategies) for legitimising the order of power and affirmation of 
the projected reality, but also in the aforementioned context of social engagement and reshaping the experienced world. It should be emphasised that aesthetic criteria and artistic preferences are more than just a form of nostalgia for an orderly world. The political power of art has always been based on a confrontation between that which represents rationalised and relatively stable past, and the volatile present which evades discourse. It has predominantly been based on the dynamics of opposing forms and complementary contents. That is why art has aroused interest of theoreticians and creators alike, who, after all, attempted to explore the principles underlying the interaction of power structures, artistic forms and aesthetic criteria.

Artistic power over form could exist as a parallel to political power. However, in the processes described, the awareness of such power did not lead artists to revolutionary changes, but merely attempts to redefine their social function. The alliance between power and art explored by modernity was nevertheless based on a conscious, successive and aesthetic profiling of politics and found its expression in propaganda mechanisms used for its glorification. This way artistic means were used in an instrumental way to popularise political and social ideas, which was realised in specific forms and iconographic motives. Propaganda annexed intermediate forms represented by symbols and signs and took on a sensual shape which related directly to the emotive sphere, while the reflection on the establishment of power merged with artistic order.

\section{III}

In the complicated history of Poland, filled with political disasters and patriotic uprisings, a functional merge of the aesthetic and the political appeared to be a natural process, which in addition instrumentalised all artistic activities in order to effectively submit them to the goals set by the high authority or interests of the emancipating nation. Therefore, disputes on the usefulness of artistic practices in shaping the national identity and awareness occurred within the field of modernist manifestos. Already at that time, artists were shown a perspective of designing the future world, being capable of regulating its formal complexity and establishing the field of power. It was recognised that art had a transformational potential and as such could become a useful reshaping and constructing tool for the animators of the new reality, who wished to modify the established hierarchies. Art was seen as an instrument of political transformation in the world.

Based on these observations, what emerged as the most popular term to describe the nature of relations between power and art was "politicisation" understood as ideological involvement that made art a hostage of the political regime in power at a given time. However, the meaning of the term "political" cannot be reduced to institutionally grounded processes of exercising and distributing power. It can refer to more extensive phenomena pertaining to the entire sphere of social life and every kind of organisation or configuration of experience. We can therefore assume that politics is not only about holding power or struggling for it - it is also about managing a specific space and dividing a particular sphere of experience.

One can have doubts, however, about the role of contemporary art within modern societies, especially about how its mechanisms, techniques and strategies have been used to secure new forms of power. This doubt can be inscribed in the wider context of discussions on the position of modern art, the status of works of art and social roles of artists, but also the institution of art itself, which changes in the time of transformation. In the context of political transformation in Poland, this is related to the role of artistic practice in shaping a new model of life. Analysis of the domain of aesthetics may prove helpful to describe these interrelations. A cognitive 
perspective found in the works of Jacques Rancière might also prove useful. The author of The Politics of Aesthetics argues that apolitical art does not exist due to the fact that all forms of artistic activity lead to modification and aesthetic reshaping of the world; therefore, in their essence, they reconfigure the field of our experience, providing it with a new spatial order. In consequence, one could hardly imagine an artistic act — or any recreation — that would not involve some transformational power. Art understood in this way is "not politics because of messages or feelings related to that the world order it communicates. Neither is it politics for the way in which it shows the social structure, conflicts or identities of social groups. Art is politics through the very distance taken towards its functions, through the type of time and space introduced, through the way it divides that time and peoples that space" [Rancière, 2007: 24]. This specific configuration of time and space as forms of sensuality demarcating the sphere of experience creates the basis for designing a future society.

For this reason, when discussing the postulates of socially engaged art one should emphasise various attitudes towards the political involvement of art and active reshaping of social life. In 2007, Artur Żmijewski published his artistic declaration titled Applied social arts. Its publication in "Krytyka Polityczna" coincided with the first Polish edition of Jacques Rancière's writings The Politics of Aesthetics. In his declaration, Żmijewski tried to draw our attention to social consequences of creative activity, their transformational potential and cognitive usefulness - an important element broadening the field of artistic works and enabling artists to truly contribute to reshaping the world [Żmijewski, 2007]. According to Żmijewski, recognition of the political power of an artistic gesture was not enough to substantially influence the shape of social life. Hence the postulated effectiveness, which should be generated by abolishing the established restrictions, among which, as the author believes, are: placement of art in the position of an outsider, isolation of art from other discourses, the related alienation and ignorance of artists and critics and finally the impossibility of verifying achievements. In order to restore art's direct influence on social and political life, one should stop treating artistic realisations as mere symptoms - they have a real "power to name, define and interfere in cultural structures, power to put pressure on elements of social structure by including them in artefacts" [Żmijewski, 2007: 17]. Artists themselves should stop being afraid of the effects of their actions by finding a Solomonic solution between serving the power and an open rebellion.

Artists, therefore, should not refrain from engaging in social debate and stating their political preferences regardless of past, perhaps difficult experiences, such as alliances with totalitarian regimes. The area of creativity should complement other culture-forming discourses and break the oppressive isolationism, stressing the cognitive deficit of artistic activities. In consequence, such actions should strengthen the interactive potential of art. This way art would be able to intensify social engagement, while artists could profile their activities in a way that would lead to reconfiguring the network of relations shaping the sphere of common experience. This is especially true when the artistic project anticipates far-reaching social effects, including bond strengthening or community resuscitation, which seemed particularly relevant during the transformation period. Moreover, the artistic appropriation of public space connected with this activity influences the assimilation of creative strategies and the transfer of artistic forms into popular culture.

One should also abandon the tradition of instrumentalising artistic practice and rather than treat politicisation in terms of alliance with power, see it as a real change, reconfiguration of life. Only real involvement, described as participation, eliminates the state of being closed within the autonomous field of art sanctioned by modernity, eradicates isolation, autotelicity and distance 
from problems that go beyond the artistic practice. Therefore, it succours all the postulates that would like to see art as the tool for reconstructing reality. Any artistic or aesthetic idea, by means of which social reality is organised, gains political power to reconfigure the experience and modify the established hierarchies. Thus, it can be concluded that the twentieth-century transformations of social space have confirmed the belief held by Rancière and others that all spheres of life are "politicised."

\section{IV}

What is characteristic of the Polish setting, however, is a conviction that attitudes towards art are always polarised and translate into mutually exclusive, antagonised "front lines" in a battle for the "quality" of artistic expression. However, when modelling dissensuality of political narratives is added to the picture, it becomes more complicated. Hence the continuous creation of new partitions, parcelling and demarcation strategies, separating not only the fields of artistic exploration, but also the audience. This also leads to far-reaching simplifications in the critical layer and highlights not so much the heterogeneity of artistic practices, but rather the reduction of the balance of forces within the field of art to a dichotomous alignment. However, the idea of polarisation can be a convenient and simplifying interpretation key. This is exemplified by the attempts to critically reflect on Polish contemporary art. Agata Pyzik, for instance, writes that in Poland ,there are two attitudes towards modern art: one involves ignorance and right-wing censorship of institutions succumbing to the pressure of the church or authorities, and the most primitive accusations of offence to feelings, moral debasement or pointless "daubs"; the other is based on full acceptance of the primacy of monetary value, where art is only for the sophisticated and affluent, and as such should primarily be part of the "market", where the status of an artist / his art is indicated by his market position" [Pyzik, 2017]. A similar attempt to present the recent political involvement of the Polish art was made by Jakub Banasiak. While evaluating this year's exhibitions (Późna polskość/Late Polishness at the Centre of Modern Art, curated by Ewa Gorządek and Stach Szabłowski and Historiofilia/Historyphilia at Drukarnia NaukowoTechniczna, curated by Piotr Bernatowicz), he focuses only on the continuing fundamental dispute between two conflicted parties of the Polish political scene [Banasiak, 2017].

Naturally, both these opinions are founded on the belief that the very nature of art is political. If so, its political potential can (or rather: should) be used. However, when an artistic work becomes a "manifesto", some questions arise: to what extent can artists be politically engaged? To what extent can they associate their creative work with active support for political movements? What limits their creative activity? Do such boundaries, determined by the socalled political correctness, make sense? After all, distancing oneself from experience, from what is spectacular, implies exclusion from social circulation and means marginalising and suppressing one's own views and political demands, and consequently leads to loneliness and powerlessness. Political emancipation is the only type of emancipation that involves a transfer of a given form of subjectivity into the sphere of political "visibility", the ability to manifest one's ability to manage the field of experience, to attract attention, and to communicate one's presence and strength (social importance). At the opposite extreme, there are those who are always excluded, deprived of their "voice", i.e. the politically powerless.

However, is such disengaged "visibility" possible? Part of the artistic community declares a kind of "neutrality". While commenting on the creation of one of the most controversial installations located in the centre of Warsaw (Tęcza/Rainbow, 2012), Julita Wójcik claimed that 
she was not involved either socially or politically, because she tried to purge this project from any dedicated meanings to generate pure pleasure. Another form of distance and non-alignment was postulated by the artists associated with the Noo-avant-garde Manifesto (Agnieszka Kurant, Oskar Dawicki, Łukasz Ronduda, Janek Simon and Edwin Bendyk), who made lack of commitment one of their postulates, arguing that any form of engagement could deprive the work of art of its artistic value (Niezwykle Rzadkie Zdarzenia. Dystrybucja Nooawangardy/ Extremely Rare Events. Distribution of Noo-avant-garde, Centre of Modern Art 2009).

The problem, however, is not whether artists consciously enclose their works with sociopolitical content, or whether they try to defend themselves against such an association, distancing themselves and choosing various strategies of escapism. Rancière's perspective demonstrates the impossibility of separating these two areas, with art making certain objects "visible" and thus taking control over the techniques of their representation. As a result, there are no enclaves in which artists could be isolated from power. After all, they themselves authenticate this power. Therefore, their decision can only relate to real engagement.

Thus, only a broad understanding of creative activities allows for overcoming the barriers that isolate art from other areas of social life and select groups of its recipients. However, what is most often observed is the politicisation of artistic practices, rather than liberation of their critical power, intervention or correction postulated by the creators engaged. Hence the actions that usually instrumentalise art acquire performative, spectacular and transparent traits. Żmijewski noticed that the "the oldest and most important tradition of art" is conformism, not rebellion. The latter is a marginal phenomenon since "art is rather a tool that makes people conform, makes them stay loyal to their own rules" [Żmijewski \& Warsza, 2012]. For those in power, the phantasmal figure of the artist - alienated, irrational and anti-social, and therefore powerless - is the most useful one. A gesture of visibility on its own (lending visibility) seems to be insufficient - in order to be effective, the artist should become the animator.

This might explain why the transformational potential of art was used to such a small extent in the time of political transformation in Poland. The artistic and social orders were not correlated despite creators' commitment. The power of art, or the possibility of real influence on the shape of social life, was limited by the expedient inertia, institutional immaturity, isolation of art from other discourses, and the need to construct a myth conditioned by political alliances, i.e. a unified, coherent narrative that would precisely dislocate objects of experience and enrich the imaginaries. In fact, all regimes have used and distorted the artistic and intellectual heritage of their time, controlling the sphere of creativity and turning the effects of artistic practices against artists or persuading them to obligingly deform the experienced world. Therefore, what could be expected from art born on the ruins of a totalitarian system is distanced and critical authenticity, free from collaboration with the ruling regime. However, art is already fulfilling its new task, i.e. it is reconfiguring the world, establishing its new hierarchies and setting new boundaries of experience; artists either critically deconstruct the mechanisms of power and oppression or exploit them to achieve their own goals. Perhaps, following this trail, one should assume the possibility of a specific "feedback", a subversion mechanism that would go beyond simple manipulation of the results of artistic practices. This feedback would neutralise the oppressiveness of political power over not only creative actions, but also strategies for their interpretation, and thus enable autonomous re-interpretation, a free play with conventions appropriated by the authorities. Only then could art become a powerthreatening field of critical activity. 


\section{References}

Banasiak, Jakub. Lata 90: Bez-czas i czasy równoległe. “Dwutygodnik” 06/2011. http://www. dwutygodnik.com/artykul/2271-lata-90-bez-czas-i-czasy-rownolegle.html (15.10.2017).

Banasiak, Jakub. Ironiści i kontrrewolucjoniści, czyli artystyczna wojna III i IV RP. "Szum" 11.08.2017. https://magazynszum.pl/krytyka/ironisci-i-kontrrewolucjonisci-czyliartystyczna-wojna-iii-i-iv-rp (10.10.2017).

Foucault, Michel. Wykład z 28. stycznia 1976. in: Foucault, Michel. Trzeba bronić społeczeństwa. Wyktady z College de France 1976. transl. Kowalska, Małgorzata. Warszawa: Wydawnictwo KR, 1998: 71-89.

Krajewski, Marek, and Filip Szmidt. Wizualne/niewidzialne. Sztuki wizualne w Polsce. Stan, rola i znaczenie. Najważniejsze ustalenia badawcze. Warszawa: Akademia Sztuk Pięknych, 2016.

Pyzik, Agata. Nie chcieć żadnego skutku. Skuteczność sztuki. „Szum” 26.09.2015. https:// magazynszum.pl/krytyka/nie-chciec-zadnego-skutku-skutecznosc-sztuki/ (15.10.2017).

Rancière, Jacques. Estetyka jako polityka. transl. Kutyła, Julian. Mościcki, Paweł. Warszawa: Wydawnictwo Krytyki Politycznej, 2007.

Sowa, Jan. Cień transformacji. Autoportret. Pismo o dobrej przestrzeni, Nr 3 (54) 2016.

Szabłowski, Stach. Sarmata kontra "Naziści”. Zniszczenie wystawy Piotra Uklańskiego "Naziści" przez Daniela Olbrychskiego. http://www.nck.pl/kongres-kultury/48449-sarmata-kontranazisci-zniszczenie-wystawy-piotra-uklanskiego-nazisci-przez-daniela-olbrychskiegostach-szablowski/ (20.10.2017)

Żmijewski, Artur. Stosowane sztuki społeczne. Krytyka Polityczna, Nr 11/12 2007: 14-24.

Żmijewski, Artur, and Joanna Warsza. Żmijewski: zuniwersalizować wyjątek. Artur Żmijewski w rozmowie z Joanną Warszą, Krytyka Polityczna 6.01.2012, http://krytykapolityczna.pl/ kultura/zmijewski-zuniwersalizowac-wyjatek/ (20.10.2017). 